\title{
Review
}

\section{Lived fictions: Unity and exclusion in Canadian politics}

\author{
John Grant \\ University of British Columbia Press, Vancouver, 2018, ix+292, \\ ISBN:978-0-7748-3648-7
}

Contemporary Political Theory (2021) 20, S21-S24. https://doi.org/10.1057/s41296020-00388-3; published online 12 March 2020

In this book, John Grant accomplishes several achievements, any of which would be impressive on their own. He speaks effectively to both political theorists and Canadian politics specialists on complex matters of political ideology as lived experience, while crafting a discussion accessible to politically engaged Canadians. He recasts dialectical analysis as a valuable tool for critical political theory that leaves its rarified comfort zone to demonstrate the potential of 'non-ideal theory'. The demonstration takes the form of an empirically rich, theoretically rigorous critique of four troubling deficiencies in Canadian political life, informed by insightful readings of canonical and contemporary political philosophy. And to address these democratic deficiencies, Grant ends with a compelling call for specific institutional and policy changes consistent with a radical vision of democratic promise.

The author presents this work as motivated by the early Frankfurt school's view of theory's proper relation to politics: 'theory becomes critical only when it takes society as its object and pursues emancipatory aims and intentions' (p. 7). Following this lead, he investigates concrete instances of how pathologies of reason emerge in modernity from the exercise of unequal economic, socio-cultural, and political power. The modernity presented here has a clearly Canadian character, but Grant's immanent critique of distinctively Canadian pathologies of reason and power will illuminate lived political fictions in many countries.

Chapter one presents Western political thought through the prism of a search for unity by 'sovereign imaginaries' that intentionally exclude and socially marginalize dominated minorities. Grant maintains that whatever they have claimed in the name of reason, freedom, or equality, virtually all canonical thinkers have presented sovereign imaginaries, supported by a succession of more concrete 'lived fictions', that entailed and required relations of exclusion and dominance. He follows this theme through the case studies in the volume, arguing that lived fictions of Canadian constitutionalism, multiculturalism, welfare state transformation, and

(c) 2020 Springer Nature Limited. 1470-8914 Contemporary Political Theory Vol. 20, S1, S21-S24 
relations between a settler state and Indigenous peoples have grounded their legitimacy, while masking their inherent exclusion and dominance, in a quest for some form of unity.

Grant's analysis in this volume continues his project, begun in Dialectics and Contemporary Politics (2011), of recasting dialectical relations as an interplay between moments of dependence, antagonism, and production. In Lived Fictions, this conceptualization of dialectics frames analysis of how specific political imaginaries and lived fictions sustain changing, multiple, and undemocratic relations of power. The dialectical dimension of Grant's analysis gains much of its value from numerous illustrations of how these dynamic fictions, co-created and reinforced at different levels by intellectuals, politicians, and cultural elites, have simultaneously influenced and had their agendas set within institutionally specific political economies. These illustrations draw on an impressive range of secondary literature by Canadian and comparative social scientists, as well as official statistical and public opinion data.

In chapter 2, Grant investigates the potential of four recent accounts of 'political imaginaries' to reveal important insights about ideology and power. Finding them promising but lacking in truly critical insight into the most troubling pathologies of reason in contemporary politics, he constructs his own concept of 'lived fiction'. This term conveys the dialectical interplay between ideology, institutionalized power, and the lived experience of ordinary citizens, the powerful, and those who variously support or translate that power in specific political communities. As he puts it, lived fictions are not just 'socially effective illusions', they also 'construct and orient our sense of ourselves and our practices within society', while remaining 'fictions insofar as they distort features of our lived experience in such a way that that allows for harmful inequalities and relations of dominance to take root'. Yet he insists that this is not just illusion, on the one hand, and oppression, on the other; there is enough truth in each of the lived fictions to ensure that the 'lived and the fictitious [are] not only opposites but also mutually interactive and dependent features of social life' (p. 6).

The kinds of evidence that Grant assembles for his four case studies suggest that the dialectical character of these lived fictions is necessarily but not always primarily anchored in the developments and dynamics of political economy, broadly understood. In other words, as he argues in detail in Dialectics and Contemporary Politics, we should not limit our examination of dialectical relations to 'contradictions' in the mode of production. His investigation of four powerfully important Canadian lived fictions, across four tightly argued chapters, is intended to deepen our understanding of both ideology and dialectics by focusing on relevant aspects of dependence, antagonism, and production.

Grant's four case studies in Lived Fictions build a normative and critical theoretical basis for his eventual advocacy, in Chapter 7, of radical democratic innovations that can transform elements of dominant sovereign power into 
democratizing constituent power. Chapter 3, on Canada's 'constituent power problem', lays out the constitutional foundations and key academic interpretations of what Grant portrays as a continual undermining of potential collective democratic empowerment by citizens. The next three chapters mount a careful yet frontal assault on recent policies and arguments that support three other lived fictions central to the antagonism between sovereign and popular power in Canada: relations between the settler state and Indigenous peoples, the transformation of the welfare state, and multiculturalism. In Chapter 4, Grant argues that the mutual constitution of lived fictions and public policies has been especially damaging, and destructive of democratic constituent power, in the enduringly colonial relations between Indigenous peoples and the Canadian settler state. And in chapter 5, Grant contends that as in much of the West, 'embedded neoliberalism' has largely replaced embedded liberalism as the dominant lived fiction animating the Canadian welfare state. He critically assesses Canadian multiculturalism in chapter 6 as a combination of demographic, attitudinal, and policy realities. He argues, contra Kymlicka and many Canadian commentators, that recent immigrants have been expected to integrate into pre-existing Canadian norms and practices almost to the point of cultural assimilation. For Grant, the underlying relations of dominance and 'excluded inclusion' within our version of multiculturalism reveal a troubling hypocrisy in the frequent Canadian celebration of equality in diversity.

Grant devotes his last chapter to discussion of three democratic innovations. The first is a qualified argument for Citizens Assemblies (CAs). He insists that these have democratic potential to contribute to constituent power only if they are empowered, not simply preludes to referendums or bodies making non-binding recommendations to cabinet. He proposes proliferation of CAs over a wide range of policy domains to demonstrate and incubate citizens' capacities for constituent power. His other two proposals are for a generous version of the guaranteed annual income and a free market-defying imposition of income ratios on the gap between business owners' and employees' incomes. These policies are intended to empower citizens as co-participants in constituent power, while undercutting harmful social inequalities. This suite of proposals underscores Grant's journey from ideal to nonideal critical theory since his 2011 book.

In Lived Fictions, John Grant engages a wide variety of prominent social and political theorists. He doesn't spare them criticism when their arguments' implications suggest a failure to clear the high bar he sets for radical critique or democratic imagination. Three Canadian political theorists - Charles Taylor, James Tully, and Will Kymlicka - come in for serious criticism. He finds that their appreciation of the material, institutional, and ideational or discursive bases of political, economic, and cultural power is insufficiently dialectical, insufficiently revealing of the logics of unequal political power, and insufficiently supportive of promising avenues for democratic innovation. On the other hand, almost in passing, Grant quotes C.B. Macpherson at length on the first three assumptions of 
'possessive individualism', suggesting Macpherson's prescience about the logic of neoliberalism (p. 79).

Despite Macpherson's analytical allergy to continental European concepts like 'dialectics', his Possessive Individualism is an oddly exemplary demonstration of the value of dialectical analysis. In Possessive Individualism, Macpherson's 'dialectical' interpretive move was to situate the work of 17th century English political thinkers in the context of an emerging capitalist market economy in Britain, and then argue that these thinkers adopted assumptions about human nature and social relations specific to the logic of capitalist political economies. Macpherson's writings on democratic theory - especially Democracy in Alberta (1953) and Democratic Theory: Essays in Retrieval (1973) - combine elements of dialectical analysis, radical critique, and democratic imagination. So one might say that John Grant's recent work extends Macpherson's legacy in important if unexpected ways.

The irony here is that Macpherson would never have identified himself as a dialectician. This raises several questions that Grant doesn't seriously tackle in Lived Fictions but perhaps should in future work. Can one undertake radical democratic critique without an open commitment to dialectical methods? Is the democratic sovereignty of 'the common' equally theoretically imaginable, using alternate analytical methods, if it is complemented by plausible political strategies? And must critical theory qua democratic theory now operate mainly as non-ideal theory? Given the theoretical depth and innovation, political insights, and empirically well-informed commitment to an inclusive democratic future on display in Lived Fictions, John Grant is an ideal non-ideal theorist to consider such questions.

Publisher's Note Springer Nature remains neutral with regard to jurisdictional claims in published maps and institutional affiliations.

David Laycock

Simon Fraser University, Burnaby, BC V5A 1S6, Canada laycock@sfu.ca 